\title{
Project cost monitoring and control: A case of cost/time variance and earned value analysis
}

\author{
Mee-Edoiye M. Andawei \\ Department of Civil Engineering Niger Delta University Wilberforce Island AmassomaBayelsa State-Nigeria
}

\begin{abstract}
Projects are conceptualized, planned, executed and or terminated. This cycle which has a normal effort distribution agreeably obeys amongst other factors the environment within which it operates. While it is the intention of project planners to deliver the end-product within pre-determined time, cost and quality considerations, actual project performance has in most cases different from the original project management plan. This situation which is mostly noticed in the construction sector has put project managers on their toes. The paper therefore encourages the use of variance and earned value analysis to ensure cost and time compliance of all project activities. The comprehensive status framework provided by the variance and earned value analysis in this paper will assist in the more accurate assessment of project status and thereby minimizing possible project schedule and budgetary slips.
\end{abstract}

Keywords: - Cost Variance, Time Variance, Earned Value

\section{INTRODUCTION}

The needs of man are provided through series of processes. These processes, utilize men, machines, materials, space, time and other resources. This transformation process which noticeably shares the novelty of a project is a group of interrelated activities with cost, time and quality intentions. These expected product requirements are, in all cases, set out from the dream stage of the project commonly referred to as the conceptualization stage. Sequentially, a project commences as an idea of the client who intends to add value to the surrounding environment. This value addition phenomenon, in all cases, is occasioned by the desire of man to expand his boundary of influence and the renewed needs of life. It is therefore not out of place to state that the principal reason for a project is to add value to the existing environment dictated by the immediate and remote needs of man - the dominating species of the environment.

Ideally the project is required to be executed within an established budget, duration and to meet the preset quality objectives. These tripod project objectives form the basis of the project implementation strategies of today's Quantity Surveyor. These identifiable and interdependent project criteria are continually subjected to the flow of the environment, economy, and such other effects that suggests its uniqueness.

\section{CHARACTERISTICS OF PROJECT}

Projects are very different from other routine operations. They are dynamic in nature and are identified by the degree of activities, interrelatedness of activities, uncertainty, interdependence and the degree of stake-holding in its development. The key elements that are common to all projects include:

\# Timely completion.

* Completion within cost targets.

* Matching the quality parameters

\# Adherence to the technical parameters.

A set of activities that meet these four criteria is considered as a project. Unsurprisingly too, these four criteria forms the benchmark at all stages of the project development. Expectedly, any overrun experienced relating to any of the criteria would certainly attract management attention. A project plan therefore involves the activity planning, materials resource planning, human resource planning, detail specification and execution schedule and budgeting.

For each of the above to be properly planned, a couple of tools are in use as noted by Patel(2000). These include Multi-level scheduling, multi-project scheduling, CATS and RATS, MRP and MRP-11 and networking. Among these tools, network methods (PERT, GERT, CPM) are mostly used in construction works. Readers interested in the application of network techniques in managing construction works are referred to other works of the author. The choice of technique is largely dictated by the complexity of the project. While bar(gnat) charts are required for simple projects, network methods are mostly recommended for more complex projects. 


\section{PROJECT MONITORING}

In order to keep a tab on the progress of the project, a system of monitoring must be established. This, according to Patel(2000), will help in detecting deviations of the initial plan from implementation plan. It will also help in analyzing emerging problems and the likely corrective action(s) required. The comparison is either made at designated milestone(s) in the project or at specific/regular time interval(s). It is likely that some work packages will be partially completed as at the reporting date and this makes it necessary to estimate their percentage completion as a basis for comparing actual time with scheduled time of completion.

It is most desirable to note the importance of planned quality, time and cost to the project team as these form the basis of the next project action. Monitoring ensures that events do not take the project team members by surprise. It focuses more on the future than what has actually been completed thus minimizes "scope creeping".

The key areas of project monitoring are the same as the key project objectives as earlier stated in the paper. These are the project cost, time, and work quantity and quality as prepared at the planning stage of the project life. The project team in providing answers to these queries requires information from the cost, time, effort and work status reports.

\section{Cost/Time Variance analysis}

Cost/time reports compare the actual cost/time to date with the budgeted cost/time for the work accomplished to date. The report also shows the current estimate of cost/time for the entire project. The current estimate is obtained by taking the actual cost/time to date and adding an estimate of the cost required to complete the project. It shows the cost/time deviation of the project at the point of evaluation/monitoring. These deviations are mostly computed cumulatively, indicating the current project status in terms of time and cost. Note that a project that is on schedule might not necessarily be on budget and vice versa. Take for instance the following sample project information.

Table 2.Cost/Time report of sample project

\begin{tabular}{|c|c|c|c|c|c|c|c|c|c|}
\hline code & description & $\begin{array}{l}\text { Planned } \\
\text { week no. }\end{array}$ & $\begin{array}{l}\text { Budget } \\
=\mathrm{N}=\end{array}$ & $\begin{array}{r}\text { Actual } \\
\text { week } \\
\text { no. }\end{array}$ & $\begin{array}{r}\text { Actual } \\
\text { cost } \\
=\mathrm{N}=\end{array}$ & $\begin{array}{r}\text { Cum } \\
\text { Budget } \\
=\mathrm{N}=\end{array}$ & $\begin{array}{r}\text { Cum. } \\
\text { Actual } \\
\text { cost }=\mathrm{N}=\end{array}$ & $\begin{array}{l}\text { Time } \\
\text { variance }\end{array}$ & $\begin{array}{l}\text { Cum. } \\
\text { cost } \\
\text { Variance }\end{array}$ \\
\hline 0 & $\begin{array}{l}\text { Project } \\
\text { authorization }\end{array}$ & 0 & 0 & 0 & 0 & 0 & 0 & 0 & 0 \\
\hline 1 & Design approval & & & & & & & & \\
\hline & & 8 & 4,000 & 9 & 4,500 & 4,000 & 4,500 & -1 & -500 \\
\hline 2 & Foundation & 14 & 8,000 & 16 & 9,000 & 12,000 & 13,500 & -2 & $-1,500$ \\
\hline 3 & Block work & 18 & 6,000 & 20 & 9,000 & 18,000 & 22,500 & -2 & $-4,000$ \\
\hline 4 & Doors/windows & 25 & 5,000 & 25 & 5,000 & 23,000 & 27,500 & 0 & $-4,500$ \\
\hline 5 & Roofing & 29 & 12,000 & 32 & 15,000 & 35,000 & 42,500 & -3 & $-7,500$ \\
\hline 6 & Services & 30 & 7,000 & 33 & 7,500 & 42,000 & 49,500 & -3 & $-7,500$ \\
\hline 7 & Finishing & 36 & 17,000 & 35 & 15,000 & 59,000 & 64,500 & +1 & $-5,500$ \\
\hline 8 & Landscaping & 38 & 12,000 & & & & & & \\
\hline
\end{tabular}

The above cost/time report of the sample project typifies a real-life situation. The variance analysis and cost/time comparison show the "troughs" and "crests" of the project cost and duration. At week 9 work item 1 was considered completed at a cost of $=\mathrm{N}=4,500$ instead of week 8 and a budgeted cost of $=\mathrm{N}=4,000$ resulting to a cost overrun of $=\mathrm{N}=500$ and time overrun of 1 week. The situation continued until week 25 , where the project had no time overrun but still had cost overrun of $=\mathrm{N}=4,500$. At week 35 work item 6 was completed at a lower cost and 1 week earlier than the scheduled time.

Despite this interesting time performance the project still has $=\mathrm{N}=5,500$ cost overrun. This cost/time report from the above example serves as a lamp to the feet of the project manager at every status evaluation date.

\section{Milestone variance analysis}

The milestone analysis is one of the simplest methods by which project managers attempt to compare the actual against the planned costs at any point of the project. It requires only a relatively modest amount of management effort to set up and maintain. It also requires less sophisticated costing methods. In evaluating the project status, the project team would want to know the expenditure to date, projected expenditure as at date, actual and planned achievements as at date. The method involves three stages; the identification of milestone, the milestone/budget curve and the actual expenditure/actual achievement curve. 


\section{Earned value analysis}

There are other methods to measure work-in-progress of an activity. While some methods depend on judgment, others are computed analytically. Progress can be monitored, amongst others, by the units completed, incremental milestones, cost ratio and earned value method. For the purpose of this paper we shall dwell more on the earned value(performance analysis) methods. Unlike the variance analysis method, the earned value method is forward looking. It utilizes the existing project information to forecast to the project's future performance. Earned value analysis uses the worker-hour as a way to weigh the value of one activity with respect to others.

To carry out the analysis, firstly, one need to compute the percentage completion of each activity. The activity percentage completion is then multiplied by the budgeted worker-hours or naira equivalent for that activity. The result is referred to as the earned value(budgeted cost of work performed-BCWP). In assessing the project status the following equations may be necessary.

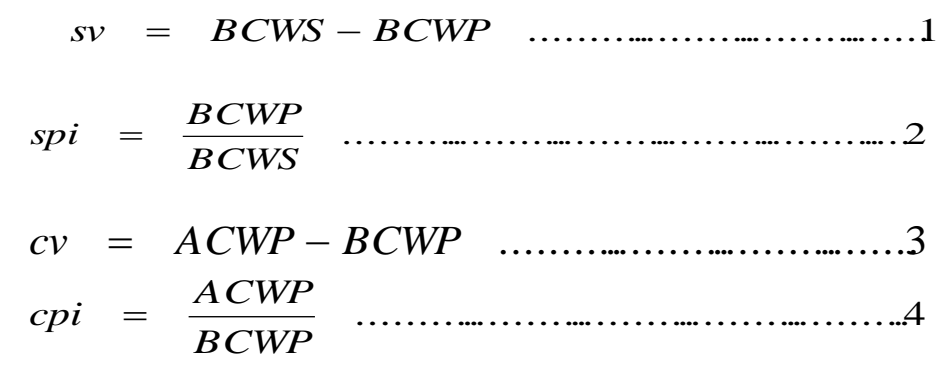

where:

$\mathrm{sv}=$ schedule variance

$\mathrm{cv}=$ cost variance

BCWS $=$ Budgeted cost of work scheduled

$\mathrm{BCWP}=$ Budgeted cost of work performed

ACWP $=$ Actual cost of work performed

spi $=$ schedule performance index

cpi $=$ cost performance index

cpi $=1$

\begin{tabular}{l|l}
$\begin{array}{l}\text { behind schedule } \\
\text { over budget }\end{array}$ & $\begin{array}{l}\text { ahead of schedule } \\
\text { over budget }\end{array}$ \\
\hline $\begin{array}{l}\text { behind schedule } \\
\text { under budget }\end{array}$ & $\begin{array}{l}\text { ahead of schedule } \\
\text { under budget }\end{array}$
\end{tabular}$\quad$ spi=1

Figure 2. Meanings of cpi and spi . Adapted from Chandra P (2003): Project: Planning, Analysis, Financing, Implementation, Review. Tata McGraw-Hill; New Delhi.

Taking a sample case with the following update information.

Table 3. Cost/Time report of sample project

\begin{tabular}{lllrrrrr}
\hline code & description & $\begin{array}{l}\text { Total } \\
\text { cost } \\
\text { forecast. }\end{array}$ & $\begin{array}{r}\text { Scheduled } \\
\text { \%completion }\end{array}$ & $\begin{array}{r}\text { Percentage } \\
\text { completion. }\end{array}$ & $\begin{array}{r}\text { Actual } \\
\text { cost } \\
\text { to date } \\
=\mathrm{N}=\end{array}$ & $\begin{array}{r}\mathrm{BCWS} \\
=\mathrm{N}=\end{array}$ & $\begin{array}{r}\mathrm{BCWP} \\
=\mathrm{N}=\end{array}$ \\
\hline 0 & Project & & & & & & \\
& authorization & 0 & 0 & 0 & 0 & 0 & 0 \\
1 & Design approval & & & & & & \\
& & 100 & 100 & 4,500 & 5,000 & 5,000 \\
2 & Foundation & 8,000 & 100 & 100 & 9,000 & 8,000 & 18,000 \\
3 & Block work & 6,000 & 100 & 50 & 9,000 & 6,000 & 6,000 \\
4 & Doors/windows & 5,000 & 100 & 60 & 5,000 & 5,000 & 5,000 \\
5 & Roofing & 12,000 & 100 & 20 & 15,000 & 12,000 & 10,000 \\
6 & Services & 7,000 & 50 & 10 & 2,500 & 3,500 & 500 \\
7 & Finishing & 17,000 & 20 & 5 & 700 & 3,400 & 1,400 \\
& TOTAL & & 0 & 0 & 45,700 & 42,900 & 45,900 \\
\hline
\end{tabular}




\begin{tabular}{|c|c|c|}
\hline SV & $\begin{array}{l}= \\
= \\
=\end{array}$ & $\begin{aligned} & B C W S-B C W P \\
&=N=42,900-=N=45,900 \\
&=N=3,000\end{aligned}$ \\
\hline $\mathrm{cv}$ & $\begin{array}{l}= \\
= \\
=\end{array}$ & $\begin{array}{l}\text { ACWP- BCWP } \\
=\mathrm{N}=45,700-=\mathrm{N}=45,900 \\
-=\mathrm{N}=200\end{array}$ \\
\hline spi & $\begin{array}{l}= \\
= \\
=\end{array}$ & $\begin{array}{l}\text { BCWP/BCWS } \\
45900 / 42900 \\
1.07\end{array}$ \\
\hline cpi & $\begin{array}{l}= \\
=\end{array}$ & $\begin{array}{l}\text { ACWP/BCWS } \\
45700 / 42900 \\
1.07\end{array}$ \\
\hline
\end{tabular}

From figure 3 above cpi>1 and spi>1. This shows that the project is ahead of schedule and over budget. One draw back of this analysis is that it does not provide answers to what is wrong with the project

\section{CONCLUSION}

Slip in project schedule and budget are common features in construction projects. This tendency, which has made monitoring and controlling functions seemingly core area of concern, has been over-sighted in construction works. The establishment of basic controlling benchmarks will assist operators of the industry to monitor and institute timely corrective action(s ) on the cost, time and quality parameters of their products.

\section{REFERENCE}

[1] M.M Andawei, Quantity Surveying in environmental management: the role of cost management and contract procedure in ensuring environmental friendliness and sensitivity in project formulation and execution, Paper presented at 2-day workshop/training program on Drawless Project-BESMM 2 organized by Nigerian Institute of Quantity Surveyors, Lagos, 2005.

[2] P. Chandra, Project: Planning, Analysis, Financing, Implementation, (New Delhi, McGraw-Hill, 2000)

[3] F.H Griffis et al, Construction Planning for Engineers (New York, McGraw-Hill Higher Education, 2000)

[4] Harris Frank and McCaffer Ronald, Modern construction management (London; Collins professional Technical Books. 1985)

[5] Dennis Lock, Project management. (London. Gower Publishing Limited.1996)

[6] K.G Lockyer, An introduction to critical path. (London; Pitman press; 1981)

[7] B.M Patel, Project: Strategic Financial Planning, Evaluation and Control(New Delhi, Vikas Publishing House PVT Ltd, 2000 